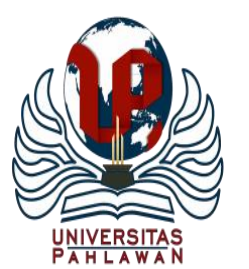

Jurnal Abdidas Volume 2 Nomor 1 Tahun 2021 Halaman 121-126

JURNAL ABDIDAS

http://abdidas.org/index.php/abdidas

\title{
Pelatihan Penggunaan Media Pembelajaran Matematika dalam Rangka Meningkatkan Motivasi Belajar Siswa
}

\author{
Isnurani $^{1}$, Ilmadi ${ }^{2}$, Aden $^{3}$, Gerry Sastro ${ }^{4}$, Nina Valentika ${ }^{5}$, Dede Nurbaiti ${ }^{6}$, Dian Sugianti ${ }^{7}$, Nisa \\ Ariffah $^{8}$, Puji Indah Lestari ${ }^{9}$, Sella Oktavian ${ }^{10}$, Siti Maesaroh ${ }^{11}$, Vingky Nurmelani ${ }^{12}$, Vivi Vitania $\mathbf{N}^{13}$, \\ Pandi Zufikar ${ }^{14}$ \\ Prodi Matematika, FMIPA, Universitas Pamulang, Indonesia ${ }^{1,2,3,4,5,6,7,8,9,10,11,12,13,14}$ \\ E-mail : dosen01193@unpam.ac.id ${ }^{1}$, dosen01926@unpam.ac.id ${ }^{2}$, dosen00527@unpam.ac.id $^{3}$, \\ dosen00544@unpam.ac.id ${ }^{4}$, dosen02339@unpam.ac.id ${ }^{5}$, dedenurbaiti@unpam.ac.id ${ }^{6}$, diansugianti16@gmail.com ${ }^{7}$, \\ nisaariffah65@gmail.com ${ }^{8}$, pujiindah145@ unpam.ac.id ${ }^{9}$, sellaoktavianiipa2@ gmail.com $^{10}$, \\ iyohmaesaroh00@gmail.com ${ }^{11}$, vingkymeilani27@ gmail.com $^{12}, \underline{\text { vivititania08@ gmail.com }}^{13}$, pandilubis65@ gmail.com $^{14}$
}

\begin{abstract}
Abstrak
Pengabdian kepada masyakarat ini bertujuan untuk memberikan pelatihan penggunaan media pembelajaran matematika dalam rangka meningkat motivasi belajar siswa di Panti Asuhan Wisma Karya Bakti Otto Iskandar Dinata. Pelatihan ini menggunakan metode Drill. Berdasarkan hasil survei yang dilakukan di lapangan memberikan kesimpulan, banyaknya siswa yang tidak mendapatkan pembelajaran dengan maksimal, hal ini disebabkan karena banyak faktor, diantaranya keterbatasan dalam pengelolaan media pembelajaran dari guru yang diberikan. Hasil analisis memberikan bahwa siswa masih memerlukan bimbingan belajar yang lebih maksimal melalui pembelajaran secara langsung dengan menerapkan protokol kesehatan. Dari hasil penelitian ini dilakukan kajian analisis terkait dampak motivasi belajar siswa setelah melalui pembelajaran jarak jauh. Metode yang digunakan dalam pelaksanaan PKM ini pembelajaran tatap muka dengan menggunakan metode drill, materi pembelajarannya yaitu : 1) memberikan materi tentang bangun datar untuk siswa kelas 7. 2) Memberikan materi tentang persamaan garis lurus untuk siswa kelas 8. 3) Memberikan materi tentang persamaan kuadrat untuk siswa kelas 9.
\end{abstract}

Kata kunci: media pembelajaran, motivasi belajar, metode Drill

\section{Abstract}

This Community Service aims to provide training in the use of mathematics learning media in order to increase student learning motivation at the Wisma Karya Bakti Orphanage Otto Iskandar Dinata. This training uses the Drill Method. Based on the results of the survey conducted in the field, it was concluded that many students did not get maximum learning, this was due to many factors, including limitations in the management of instructional media from the given teacher. The results of the analysis show that students still need maximum learning guidance through direct learning by applying health protocols. From the results of this study, an analysis study was carried out related to the impact of student learning motivation after going through distance learning. The method used in the implementation of this PKM is face-toface learning using the drill method, the learning materials are: 1) Providing material about flat shapes for class 7 students. ) Provide material about straight line equations for grade 8 students. 3) Provide material on quadratic equations for grade 9 students.

Keywords: learning media, learning motivation, Drill method

Copyright (c) 2021 Isnurani, Ilmadi, dkk

$\triangle$ Corresponding author

Address : Universitas Pamulang

Email : dosen01926@unpam.ac.id

ISSN 2721- 9224 (Media Cetak)

DOI $\quad:$ https://doi.org/10.31004/abdidas.v2i1.217 
122 Pelatihan Penggunaan Media Pembelajaran Matematika dalam Rangka Meningkatkan Motivasi Belajar Siswa - Isnurani, Ilmadi, dkk

DOI: https://doi.org/10.31004/abdidas.v2i1.217

\section{PENDAHULUAN}

Pembelajaran saat ini sedang mengalami perubahan yang sangat drastis, hal ini diakibatkan oleh adanya pandemi Covid-19 yang menuntut pembelajaran daring untuk dilaksanakan sebagai pengganti pembelajaran tatap muka. Berdasarkan Keputusan Presiden Nomor 11 Tahun 2020 terkait Penetapan Kedaruratan Kesehatan Masyarakat Corona Virus Disease 2019 (Covid-19) dan Surat Keputusan Menteri nomor: 03/KB/2020, 612 Tahun 2020, HK.01.08/Menkes/502/2020, 119/4536/SJ memberlakukan pembelajaran secara luring hanya dapat dilakukan oleh daerah yang merupakan zona hijau dan kuning dari keterpaparan pandemi covid-19. Selebihnya pembelajaran wajib dilakukan secara daring.

Sebelumnya pembelajaran daring ini belum pernah dilakukan secara bersamaan, namun pada saat ini imbas dari COVID-19 mendesak pembelajaran daring untuk dilakukan secara bersamaan (Sun et al., 2020) baik siswa, guru dan orang tua harus saling support. Mengingat waktu, lokasi dan jarak menjadi permasalahan besar saat ini (Kusuma \& Hamidah, 2020). Oleh karena itu pembelajaran daring merupakan alternatif atau solusi untuk mengatasi kesulitan pembelajaran offline. Hal ini memberikan tantangan kepada semua pihak dan jenjang pendidikan untuk menciptakankan pembelajaran tetap aktif meskipun sekolah diliburkan (Herliandry et al., 2020).

Dalam situasi saat ini siswa dituntut untuk tetap aktif dan produktif dalam proses pembelajaran, satu diantaranya dengan mengikuti forum diskusi secara daring yang dilaksanakan oleh pihak sekolah masing-masing. Pembelajaran daring bertujuan untuk membangun budaya belajar dalam menghadapi masa new normal. Hal ini dikarenakan diskusi secara daring akan menjadi budaya belajar pascapandemi Covid-19.

Sekolah dan guru harus bersikap rasional dan mampu beradaptasi dengan perubahan. Pandemi Covid-19 datang secara tiba-tiba dan mengubah semua lini kehidupan, termasuk perubahan pola pembelajaran. Oleh karena itu kesadaran untuk memperbaiki keadaan sangat diperlukan. Di tengah menghadapi new normal baik pihak pemerintah, sekolah, guru, orangtua, siswa, dan masyarakat harus memiliki kemampuan untuk belajar. Dengan adanya pembelajaran daring ini tidak jarang siswa tidak mampu menguasai setiap materi yang ada, dikarenakan kurang matangnya materi yang disampaikan. Tidak jarang pula siswa yang belum memiliki smartphone atau laptop untuk mengikuti pembelajaran daring, sehingga siswa tidak mengikuti pembelajaran yang diberikan.

Metode Drill atau latihan adalah satu diantara metode pembelajaran melalui proses latihan berulang, agar siswa memiliki kemampuan dan keterampilan yang lebih baik. Menurut Nana Sudjana (1998 : 20) metode Drill atau latihan adalah satu kegiatan berulang secara sistematis dengan tujuan untuk mengasah kemampuan dan menyempurnakan suatu keterampilan yang bersifat ajek dan lebih tinggi dariyang telah dipelajari. Karakteristik dari metode ini adalah kegiatan berulang atau pengayaan (Purwati, 2010).

Selanjutnya, menurut Haryanto (2003:40) metode Drill merupakan pembelajaran dengan 
123 Pelatihan Penggunaan Media Pembelajaran Matematika dalam Rangka Meningkatkan Motivasi Belajar Siswa - Isnurani, Ilmadi, dkk

DOI: https://doi.org/10.31004/abdidas.v2i1.217

banyak latihan atau pengayaan terhadap materi yang telah diajarkan sebelumnya sehingga siswa memperoleh pengetahuan dan keterampilan tertentu.

Roestiyah (2001:125) menyatakan "metode Drill atau metode latihan adalah suatu metode/ cara mengajar yang membuat siswa melaksanakan kegiatan-kegiatan latihan, agar siswa memiliki ketangkasan/ keterampilan yang lebih tinggi dari apa yang telah dipelajari”. Ramayulis (2010:349) menyatakan "metode Drill/ disebut latihan siap dimaksudkan untuk memperoleh ketangkasan/ keterampilan latihan terhadap apa yang dipelajari, karena hanya dengan melakukan secara praktis suatu pengetahuan dapat disempurnakan dan siap siagakan".

Rumusan masalah dalam PKM ini yaitu : 1) Bagaimana upaya meningkatan hasil belajar siswa kelas VII pada Bangun Datar melalui metode drill?, 2) Bagaimana upaya meningkatan hasil belajar siswa kelas VIII pada Persamaan Garis Lurus dan Gradien melalui metode drill?, 3) Bagaimana upaya meningkatan hasil belajar siswa pada Grafik Fungsi Kuadrat melalui metode drill?. Sementara tujuan dari PKM ini yaitu 1) Siswa mampu menghafalkan dan menuliskan simbol, rumus dan definisi, serta mempergunakan alat peraga dengan baik, 2) Siswa mampu mengembangkan kemampuan penalaran melalui proses belajar mengalikan, membagi dan menjumlahkan. 3) Siswa dapat menghubungkan dan mengkonfirmasi pengetahuan yang telah didapat.

\section{METODE}

Alternatif pemecehan masalah dilakukan dengan memberikan bimbingan serta pelatihan berupa praktik yang dibimbing langsung oleh masing-masing instruktur. Pelatihan dilaksanakan secara tatap muka selama empat hari. Praktek ini diberikan supaya siswa mampu memahami materimateri yang telah dibahas di kelas sebelumnya seperti bangun datar untuk siswa kelas 7, persamaan garis lurus untuk siswa kelas 8 dan persamaan kuadrat untuk siswa kelas 9 dengan menggunakan meted Drill. Metode ini merupakan suatu cara mengajar yang dilakukan oleh seorang guru dengan cara memberikan latihan-latihan kepada siswa agar siswa dapat lebih menguasai dan memahami tentang materi yang diajarkan serta melatih ketangkasan siswa dalam memecahkan soal.

Solusi yang ditawarkan dalam kegiatan pengabdian ini yaitu memberikan materi terkait materi-materi yang telah di bahas di kelas yakni bangun datar untuk siswa kelas 7, persamaan garis lurus untuk siswa kelas 8 dan persamaan kuadrat untuk siswa kelas 9 dengan menggunakan mtode derail karna di dasarkan bahwa pembelajaran jarak jauh tidak efisien untuk mata pelajaran matemtaika.

Sebelum Kegiatan PKM dilaksanakan, ada beberapa serangkaian persiapan sebagai berikut : 1) melakukan survei terkait motivasi belajar siswa secara akademis ditengah pandemi covid 19. 2) Melakukan wawancara mendalam tentang sejauh mana pembelajaran matematika yang telah di pelajari selama masa pandemi. 3) Menentukan tema yang relevan dengan kebutuhan yang akan 
124 Pelatihan Penggunaan Media Pembelajaran Matematika dalam Rangka Meningkatkan Motivasi Belajar Siswa - Isnurani, Ilmadi, dkk

DOI: https://doi.org/10.31004/abdidas.v2i1.217

dilaksanakan siswa dan para pengabdi. 4) Menentukan waktu pelaksanaan dan lamanya kegiatan pengabdian bersama- sama tim dosen dan para mahasiswa Universitas Pamulang. 5) Mempersiapkan materi pelatihan yang akan disampaikan pada kegiatan pengabdian kepada masyarakat.

Pelaksanaan Kegiatan Pengabdian Kepada Masyarakat berlangsung pada tanggal 19 sampai 23 desember 2020. Tim Pengabdi memberikan materi terkait dengan bangun datar, persamaan garis lurus dan persamaan kuadarat.

Mitra dalam program ini adalah siswa/siswi di Panti Asuhan Wisma Karyabakti Yayasan Ottoiskandar Dinata, Depok. Pelaksanaan kegiatan pengabdian masyarakat ini dilaksanakan pada melalui pembelajaran tatap muka dengan standar protokol kesehatab yang ketat.

Metode yang diterapkan dalam melaksanakan kegiatan pengabdian masyarakat, diantaranya sebagai berikut :1) Memberikan materi terkait bangun datar kepada siswa kelas 7, 2) Memberikan materi terkait Persamaan Garis Lurus kepada siswa kelas 8, 3) Memberikan materi terkait Persamaan Kuadrat kepada siswa kelas 9, dalam penerapan. Metode Langkah yang dilakukan yaitu : merujuk dengan beberapa cara yang digunakan untuk menyelesaikan masalah: a) memberikan penyuluhan kepada masyarakat yang bertujuan meningkatkan pemahaman serta kesadaran, b) difusi Ipteks, merupakan kegiatan yang menghasilkan produk bagi kelompok sasaran, c) memberikan pelatihan yang disertai dengan demonstrasi langsung untuk menghasilkan keterampilan tertentu, d) melakukan mediasi yang

menunjukkan pelaksana PKM sebagai mediator dalam menyelesaikan masalah yang ada dalam masyarakat, e) advokasi adalah kegiatan yang berupa pendampingan terhadap kelompok sasaran.

\section{HASIL DAN PEMBAHASAN}

Secara umum kegiatan pelatihan penggunaa metode Drill dalam mengoptimalkan pembelajaran berlangsung sangat baik dengan menaati ptotokol kesehatan. Peserta yang terdiri dari mahasiswa dan siswa/siswi di Panti Asuhan Wisma Karyabakti Yayasan Otto Iskandar Dinata, Depok sangat antusias, semangat, dan bersungguh-sungguh dalam melakukan pembelajaran secara tatap muka, mulai dari pembukaan sampai dengan dengan penutupan. Pada saat penyampaian materi banyak sekali pertanyaan-pertanyaan dari siswa kelas tujuh, delapan, Sembilan itu menunjukan adanya respon positif dari peserta tersebut sehingga tim pengabdi melakukan penambahan waktu untuk sesi pemberian materi. Begitu juga pada saat postes anak-anak sangat antusias dan bersemangat menjawab soal-soal yang diberikan oleh tim pengabdi.

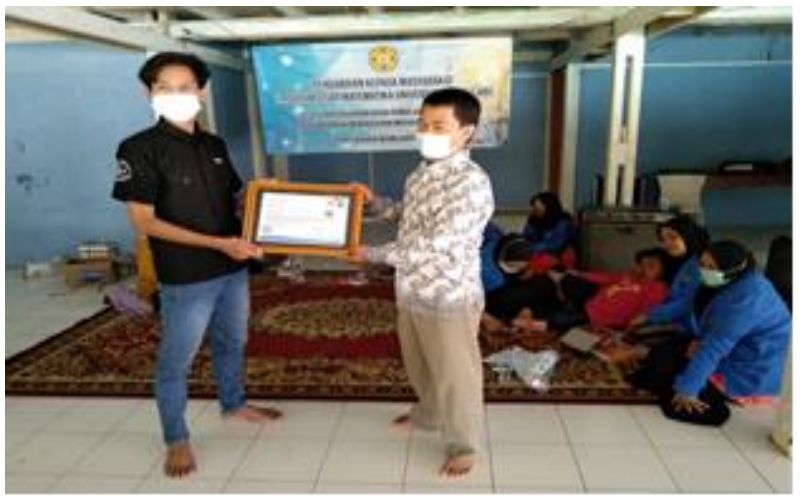

Gambar 1. Pemberian Reward terhadap Siswa Berprestasi 
125 Pelatihan Penggunaan Media Pembelajaran Matematika dalam Rangka Meningkatkan Motivasi Belajar Siswa - Isnurani, Ilmadi, dkk

DOI: https://doi.org/10.31004/abdidas.v2i1.217

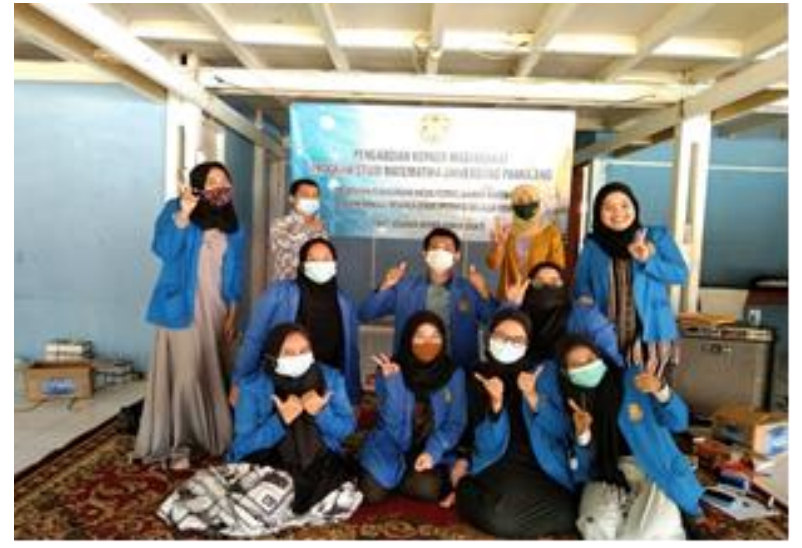

Gambar 2. Foto Barsama Tim Dosen dan Tim Panitia Pengabdian

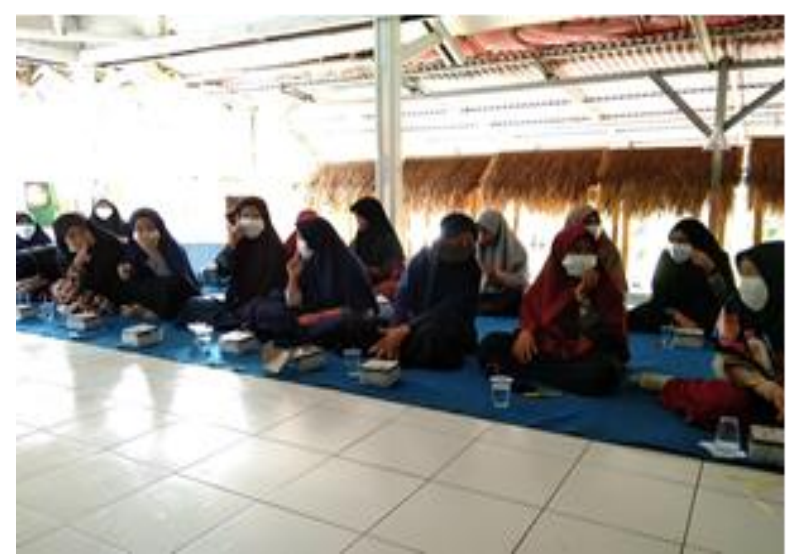

Gambar 3. Persiapan Siswa untuk Mengikuti Pembelajaran

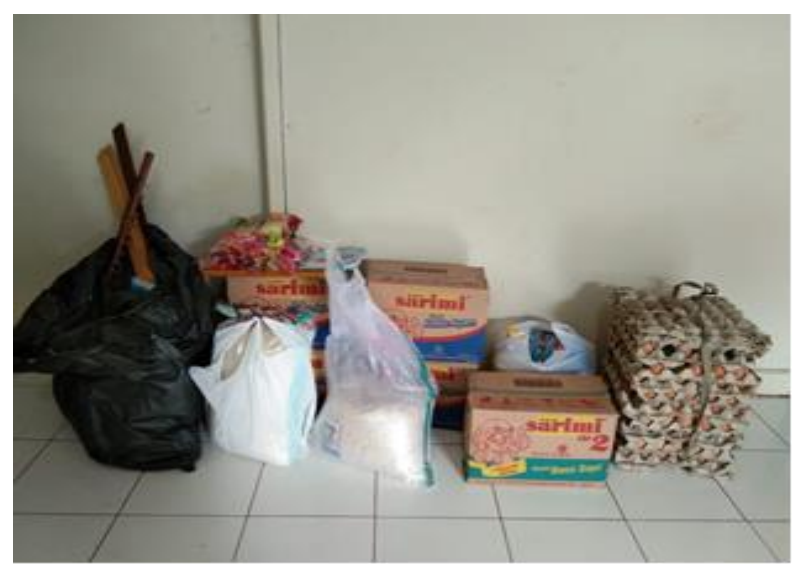

Gambar 4. Foto Sembako dari Panitia

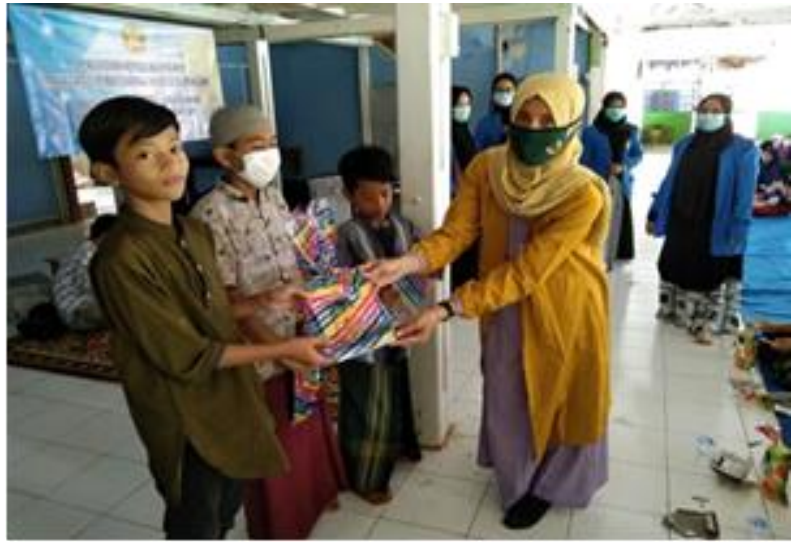

Gambar 5. Pemberian Cindramata

Penggunaan metode Drill dalam pembelajaran bangun datar sangat efektif dan efisien karna penjelasanya secara mendetail dan mudah dipahami oleh siswa. Hal ini didasarkan pada hasil rerata pretes dan postes secara signifikan mengalami kenaikan yaitu : 1) kelas 7 nilai pretes 50,62 dan nilai postes 85,$93 ; 2$ ) kelas 8 nilai pretes 33,23 dan nilai postes 59,5 ; dan 3 ) kelas 9 denan nilai pretes 42,22 dan nilai postes 63,88 . Selanjutnya jika dilihat berdasarkan jawaban siswa dalam menjawab soal bahwa secara keseluruhan siswa dapat menyelesaikan soal dengan baik.

\section{SIMPULAN}

Kesimpulan dari kegiatan pengabdian ini adalah penggunaan metode Drill dalam pembelajaran bangun datar sanagt efektif dan efisien karna penjelasanya secara mendetai dan mudah dipahami oleh siswa. Saran dari kegiatan pengabdian ini adalah diharapkan kegiatan pengabdian ini berlanjut sehingga dapat membatu siswa dalam memahami materi selama pembelajaran daring. 
126 Pelatihan Penggunaan Media Pembelajaran Matematika dalam Rangka Meningkatkan Motivasi Belajar Siswa - Isnurani, Ilmadi, dkk

DOI: https://doi.org/10.31004/abdidas.v2i1.217

\section{UCAPAN TERIMA KASIH}

Kegiatan ini berjalan dengan baik berkat bantuan dan dorongan yang cukup luar biasa dari berbagai pihak, rasa hormat dan Terimakasih kami smapaikan kepada, Rektor Universitas Pamulang, Ketua LPPM Universitas Pamulang, dan yang lainnya yang tidak bisa disebutkan satu persatu, semoga menjadi amal ibadah disisi Allah SWT.

\section{DAFTAR PUSTAKA}

Herliandry, L. D., Nurhasanah, N., Suban, M. E., \& Kuswanto, H. (2020). Pembelajaran Pada Masa Pandemi Covid-19. JTP - Jurnal Teknologi Pendidikan, 22(1), 65-70. https://doi.org/10.21009/jtp.v22i1.15286

Kusuma, J. W., \& Hamidah, H. (2020). Perbandingan Hasil Belajar Matematika Dengan Penggunaan Platform Whatsapp Group Dan Webinar Zoom Dalam Pembelajaran Jarak Jauh Pada Masa Pandemik Covid 19. JIPMat, 5(1). https://doi.org/10.26877/jipmat.v5i1.5942

Purwati, P. (2010). Pengaruh Penerapan Metode Drill/ Latihan Terhadap Minat Belajar siswa Pada Mata Pelajaran Fiqih ( Penelitian di MTS Attarbiyyah Bayongbong Garut ). Jurnal Pendidikan Universitas Garut, 04(1), $48-53$.

Sun, L., Tang, Y., \& Zuo, W. (2020). Coronavirus pushes education online. Nature Materials, 19(6), 687. https://doi.org/10.1038/s41563020-0678-8 